\title{
IDENTIFICATION OF MICROFLORA OF FRESHWATER FISH CAUGHT IN THE DRIKSNA RIVER AND POND IN LATVIA
}

\author{
Alina Kluga ${ }^{1 *}$, Miroslava Kacaniová ${ }^{2}$, Attila Kantor $^{2}$, Kaspars Kovalenko ${ }^{1}$, Margarita Terentjeva ${ }^{1}$ \\ ${ }^{1}$ Institute of Food and Environmental Hygiene, Faculty of Veterinary Medicine, Latvia University of Agriculture, Helmaña iela 8 , \\ Jelgava, Latvia, e-mail: pavlovska.alina@gmail.com \\ ${ }^{2}$ Department of Microbiology, Faculty of Biotechnology and Food Sciences, Slovak University of Agriculture in Nitra, \\ Tr. A. Hlinku 2, Nitra, Slovakia
}

\begin{abstract}
Identification of freshwater fish microflora is an important tool for evaluation of quality and safety of fish intended for human consumption. The aim of the present study was to detect the microflora of freshwater fish caught by fishermen. Altogether, 23 samples of freshwater fish were collected from fishermen from two different water sources - Driksna river and pond in Dobele. For detection of microbiological contamination, fish samples were tested for the total bacterial count (TBC), coliforms, Enterobacteriaceae and zoonotic pathogenic microorganisms - Salmonella spp., Listeria spp., and Yersinia spp. Identification of bacterial species was carried out by the MALDI-TOF MS Biotyper. TBC ranged from 2.7 to $4.78 \log _{10}$ CFU $\mathrm{g}^{-1}$ and 3.68 to $4.11 \log _{10} \mathrm{CFU} \mathrm{g} \mathrm{g}^{-1}$, coliforms from 2.55 to $4.10 \log _{10} \mathrm{CFU} \mathrm{g} \mathrm{g}^{-1}$ and 1.38 to $2.73 \log _{10} \mathrm{CFU} \mathrm{g}^{-1}$, Enterobacteriaceae from 1.95 to $4.05 \log _{10} \mathrm{CFU} \mathrm{g} \mathrm{g}^{-1}$ and 1.72 to $2.69 \log _{10} \mathrm{CFU} \mathrm{g}{ }^{-1}$ in pond and river fish samples, respectively. Between two fishing locations, fish caught in pond carried the significantly higher number of TBC, coliforms and Enterobacteriaceae than fish from the river (P>0.05). Freshwater fish microflora consisted of Pseudomonas spp. (55\%), Serratia spp. (7\%), Candida spp. (6\%), Rahnella spp. (7\%), Pantoea spp. (9\%), Aeromonas spp. (5\%), Buttiauxella spp. (8\%), Stenotrophonomas spp. (2\%) and Enterobacter spp. (1\%). Salmonella spp., Listeria spp. and Yersinia spp. were not identified. Despite the human pathogenic microorganisms were not identified in the present study, the composition of microflora and especially the abundance of Pseudomonas spp. indicates that the fish are prone to spoilage process development that potentially may alter the quality of freshwater fish meat.
\end{abstract}

Keywords: freshwater fish, bacteria, MALDI-TOF MS Biotyper

\section{Introduction}

Fish is an important source of protein for human consumption; however, the fish and fish products may contain spoilage, pathogenic and opportunistic pathogenic microorganisms, including foodborne pathogens (FAO, 2000). Foodborne pathogens may cause disease outbreaks, causing a health risk to consumers (Davies et al., 2001; Huss, 1997; Rohde et al., 2014). The presence of foodborne pathogens in fish is related to environmental conditions and microbiological quality of the water at the fishing site, because the contamination of the water and fish from animal, human and agricultural sources may occur (Feldhusen, 2000; Davies et al., 2001; Hosseini et al., 2004). Fishing method and storage conditions also may affect the microbiological quality of the fish. Fish microflora characteristics are important to determine the character of the fish microbiological contamination and consumption validity. Fish may undergo rapid spoilage process associated with intensive microbial growth that leads to rapid deterioration of the quality of the fish meat with the meat become unfit for human consumption (Austin, 2006). Consequently, to make a decision on safety of fish meat, it is important to identify and characterize the fish microflora. Fishing for consumption is very common in Latvia, but the microbiological assessment of freshwater fish caught in rivers and ponds have been not conducted yet. Therefore, the aim of the present study was to detect the microflora of freshwater fish caught by fishermen.

\section{Materials and Methods \\ Selection of samples}

Altogether, 23 freshwater fish were obtained from two different water sources - Driksna river and pond during February to June in 2015. An amount of 18 fish, including seven samples of roach (Rutilus rutilus L.), four samples of bream (Abramis brama L.), five samples of perch (Perca fluviatilis L.), one sample of chub (Leuciscus cephalus L.) and one sample of ruff (Gymnocephalus cernua L.) were caught in Driksna river located in the central part of Latvia - Zemgale district. A total of five samples of crucian carp (Carassius carassius L.) were caught in the pond located in the Dobele district in the central part of Latvia. Fish were immediately placed in a sterile container and transported to the laboratory on ice. Testing was started within 2 to $4 \mathrm{~h}$ after sampling.

Sampling

Skin, gill and gut samples of fish aseptically were taken for quantitative microbiological assessment for detection of the total bacterial count (TBC), coliforms and Enterobacteriaceae from each fish. Enterobacteriaceae were detected as the general indicator of environmental hygiene but the coliforms may signify the possible presence of pathogens able to ferment lactose. Skin samples were taken with a scalpel and a cotton swab from a $10 \mathrm{~cm}^{2}$ (depending on fish size) fish skin area near to the lateral line of the body. For gill samples, the operculum was opened first and then the gills were dissected with sterile instruments. For gut samples, the belly was cut along the midline from the anal fin and the gut content was removed. 
Pooled samples of skin, muscles and gut were used for detection of pathogens - Salmonella spp., Listeria spp. and Yersinia spp.

\section{Bacteriological analyses}

For detection of TBC, coliforms and Enterobacteriaceae counts, a quantity of $9 \mathrm{~mL}$ of $0.1 \%$ peptone water (CM0509, OXOID, UK) was added to each gill, skin and gut sample to obtain the decimal dilutions. Then, an amount of $1 \mathrm{~mL}$ of decimal dilution was plated out on Plate Count Agar (PCA, 5121452, Biolife, Italy) and incubated at $30{ }^{\circ} \mathrm{C}$ for $72 \mathrm{~h}$. After incubation bacterial colonies were counted (ISO 4833:2003). For detection of coliforms, the decimal dilutions were plated out onto Violet Red Bile Agar (VRBA, 5121852, Biolife, Italy) and incubated at $37^{\circ} \mathrm{C}$ for $24 \mathrm{~h}$. After incubation, the typical - purple, round bacterial colonies were enumerated (ISO 4832:2006). For detection of Enterobacteriaceae, the decimal dilutions were plated out onto Violet Red Bile Glucose Agar (VRBGA, 4021881, Biolife, Italy) and incubated at $37^{\circ} \mathrm{C}$ for $24 \mathrm{~h}$. After incubation, the typical purple colonies were enumerated (ISO 21528-2:2004).

For detection of L. monocytogenes, a suspension of the sample in Half-Fraser broth (BO0793, OXOID, UK) with ratio $1: 10$ was incubated at $30{ }^{\circ} \mathrm{C}$ for $24 \mathrm{~h}$ (ISO 11290-1:2005). After incubation, a quantity of $0.1 \mathrm{~mL}$ of suspension was transferred into Fraser broth (CM0895, OXOID, UK) and incubated at $37{ }^{\circ} \mathrm{C}$ for $48 \mathrm{~h}$. An amount of $0.1 \mathrm{~mL}$ of Half-Fraser and Fraser broth was plated out on Palcam (401604, Biolife, Italy) and Agar Listeria Ottaviani \& Agosti (ALOA, 4016052, Biolife, Italy) and incubated for 24-48 h at $37{ }^{\circ} \mathrm{C}$. After incubation, the agar plates were checked for the presence of typical blue with opaque halo colonies on ALOA and grey colonies with a black halo on Palcam agars. Typical colonies were Gram stained and were tested for catalase activity, haemolysis and the biochemical identification was performed.

For detection of Salmonella spp., a suspension of the sample in $0.1 \%$ buffered peptone water with ratio $1: 10$ was incubated at $37{ }^{\circ} \mathrm{C}$ for $24 \mathrm{~h}$ (ISO 6579:2006). After incubation, a $0.1 \mathrm{~mL}$ of the suspension was transferred into $9 \mathrm{~mL}$ of Rappaport-Vassiliadis (5119802, Biolife, Italy) and Muller Kauffmann Tetrathionate broths (4017452, Biolife, Italy) for selective enrichment at $37{ }^{\circ} \mathrm{C}$ for $24 \mathrm{~h}$. After incubation, a $0.1 \mathrm{~mL}$ of the enriched broth was plated on Xylose Lysine Deoxycholate Agar (XLD, 4022082, Biolife, Italy) and incubated at $37^{\circ} \mathrm{C}$ for $24 \mathrm{~h}$. Then, the plates were checked for the presence of typical pink to red colonies with black centers, which were transferred in Triple Sugar Iron Agar containing tubes (TSI, CM0277, OXOID, UK) and incubated at $37^{\circ} \mathrm{C}$ for $24 \mathrm{~h}$. After incubation, the agar tubes were checked for glucose, lactose and sucrose fermentation.

Suspension of the sample in Peptone Mannitol Bile Salt Broth (1:10) (PMB, $10.0 \mathrm{~g}$ bacteriological peptone, LP0037, OXOID, UK; $10.0 \mathrm{~g}$ mannitol for microbiology; $1.2 \mathrm{~g}$ bile salts No.3; $7.5 \mathrm{~g}$ d-sodium hydrogen phosphate, Scharlau Chemie S.A., Barcelona, Spain) was plated out onto Cefsulodin Irgasan Novobiocin Agar (CIN, 401302, Biolife, Italy) at $30{ }^{\circ} \mathrm{C}$ for $24 \mathrm{~h}$ for detection of Yersinia spp. (ISO 10273:2003). In the case of negative results, the suspension was incubated at $4{ }^{\circ} \mathrm{C}$ for 14 days with subsequent treatment with $0.5 \% \mathrm{KOH}$ before the culturing. Inoculated plates were incubated at $30{ }^{\circ} \mathrm{C}$ for 24-48 $\mathrm{h}$ and then checked for the presence of typical colonies with red centre and translucent outer zones. Typical colonies were checked for urea hydrolysis (UREA agar, CM0053, OXOID, UK).

Identification of microbial microflora with MALDITOF Biotyper MS

MALDI-TOF Mass Spectrometry was applied for the identification of bacteria. Bacterial colonies from PCA, VRBA and VRBGA agars were plated onto Tryptone Soya Agar (TSA, CM0131, OXOID, UK) and inoculated at $37^{\circ} \mathrm{C}$ for $18-24 \mathrm{~h}$.

The colonies from the TSA were transferred in $300 \mu \mathrm{L}$ of sterile distilled water and $900 \mu \mathrm{L}$ of absolute ethanol (99\%, Sigma-Aldrich, USA) was added. The mixture was centrifuged at $13000 \times \mathrm{g}$ for $2 \mathrm{~min}$. After removal of the supernatant, residual ethanol was pipetted and the pellet dried at a room temperature. Then, a $10 \mu \mathrm{L}$ of formic acid $(70 \%)$ and $10 \mu \mathrm{L}$ of acetonitrile (100\%) was added to the pellet and mixed. The solution was centrifuged repeatedly and the supernatant was transferred on a polished MALDI plate (Bruker Daltonics, Germany). Then, a $1 \mu \mathrm{L}$ of the matrix solution (HCCA: $\alpha$-cyano-4-hydroxycinnamic acid, $50 \%$ acetonitrile with $0.025 \%$ trifluoroacetic acid. Samples were processed in the MALDI-TOF MS (Microflex LT/SH, Bruker Daltonics) and results were obtained with Realtime Classification software (RTC) (Bruker Daltonics).

\section{Statistical analyses}

All microbial counts data were transformed to decimal logarithms.

T-tests for calculating differences among the TBC, coliforms and Enterobacteriaceae in different samples and fish species were applied.

\section{Results and Discussion}

The highest TBC was found on skin, gills and gut of roach with 3.95, 4.63 and $4.39 \log _{10}$ CFU g-1 (Table 1). The highest number of coliforms and Enterobacteriaceae counts were in ruff skin, gill and gut samples, comprising 3.00, 3.66 and $4.10 \log _{10}$ $\mathrm{CFU} \mathrm{g} \mathrm{g}^{-1}$ and 4.71, 3.67 and $2.66 \log _{10} \mathrm{CFU} \mathrm{\textrm {g } ^ { - 1 }}$ for coliforms and Enterobacteriaceae, respectively. TBC ranged from 2.72 to $4.78 \log _{10} \mathrm{CFU} \mathrm{g}^{-1}$ in crucian carp skin and gill samples, respectively. Coliforms were detected in all samples and the highest coliform count was $4.10 \log _{10} \mathrm{CFU} \mathrm{g}^{-1}$ in gill but the lowest of $2.55 \log _{10}$ CFU $\mathrm{g}^{-1}$ in skin. The highest Enterobacteriaceae counts of $4.05 \log _{10} \mathrm{CFU} \mathrm{g} \mathrm{g}^{-1}$ were in gills while the lowest of $1.95 \log _{10} \mathrm{CFU} \mathrm{g} \mathrm{g}^{-1}$ in skin samples. 
TBC, coliforms and Enterobacteriaceae $\left(\log _{10} \mathrm{CFU} \mathrm{g}^{-1}\right)$ in freshwater fish caught in Driksna river and pond

\begin{tabular}{|c|c|c|c|c|}
\hline Fish species & Sampling site & $\begin{array}{c}\text { TBC } \\
\text { Mean } \pm \text { SD }\end{array}$ & $\begin{array}{l}\text { Coliforms } \\
\text { Mean } \pm \text { SD }\end{array}$ & $\begin{array}{c}\text { Enterobacteriaceae } \\
\text { Mean } \pm \text { SD }\end{array}$ \\
\hline Chub & Skin & 3.46 & 0 & 2.26 \\
\hline \multirow{2}{*}{ (Leuciscus cephalus) } & Gills & 3.04 & 2.26 & 0 \\
\hline & Gut & 4.42 & 3.07 & 3.32 \\
\hline \multirow{3}{*}{$\begin{array}{l}\text { Roach } \\
\text { (Rutilus rutilus) }\end{array}$} & Skin & $3.95 \pm 1.08^{\mathrm{a}}$ & $1.29 \pm 1.22^{b}$ & $0.60 \pm 1.03^{\mathrm{c}}$ \\
\hline & Gills & $4.63 \pm 0.42$ & $2.82 \pm 1.29$ & $2.79 \pm 1.38$ \\
\hline & Gut & $4.39 \pm 0.57$ & $2.96 \pm 0.46$ & $1.97 \pm 1.41$ \\
\hline \multirow{3}{*}{$\begin{array}{l}\text { Bream } \\
\text { (Abramis bram) }\end{array}$} & Skin & $3.26 \pm 0.52^{\mathrm{a}}$ & $0.49 \pm 0.98^{b}$ & $1.55 \pm 1.04$ \\
\hline & Gills & $3.49 \pm 0.75$ & $2.54 \pm 1.79$ & $2.30 \pm 1.54$ \\
\hline & Gut & $3.86 \pm 0.62$ & $2.05 \pm 1.37$ & $1.06 \pm 1.22^{\mathrm{c}}$ \\
\hline \multirow{3}{*}{$\begin{array}{l}\text { Perch } \\
\text { (Perca fluviatilis) }\end{array}$} & Skin & $3.98 \pm 0.71^{\mathrm{a}}$ & $2.17 \pm 1.43$ & $2.73 \pm 0.93$ \\
\hline & Gills & $4.12 \pm 1.34$ & $2.66 \pm 1.56$ & $3.19 \pm 0.63$ \\
\hline & Gut & $4.15 \pm 0.53$ & $2.39 \pm 1.48^{b}$ & $2.74 \pm 0.61^{\mathrm{c}}$ \\
\hline \multirow{3}{*}{$\begin{array}{l}\text { Ruff } \\
\text { (Gymno-cephalus cernua) }\end{array}$} & Skin & 2.26 & 3.00 & 4.71 \\
\hline & Gills & 3.49 & 3.66 & 3.67 \\
\hline & Gut & 2.66 & 4.10 & 2.66 \\
\hline \multirow{3}{*}{$\begin{array}{l}\text { Crucian carp } \\
\text { (Carassius carassius) }\end{array}$} & Skin & $2.72 \pm 0.46^{\mathrm{d}}$ & $2.55 \pm 0.36^{\mathrm{d}}$ & $1.95 \pm 1.15^{\mathrm{d}}$ \\
\hline & Gills & $4.78 \pm 0.36$ & $4.10 \pm 0.34$ & $4.05 \pm 0.38$ \\
\hline & Gut & $4.54 \pm 0.62$ & $3.64 \pm 0.71$ & $3.25 \pm 0.72$ \\
\hline \multicolumn{5}{|c|}{$\begin{array}{l}\text { a no significant differences between TBC in roach, bream and perch skin, gill and gut samples were observ } \\
\text { b coliforms in roach and bream skin samples was significantly less than in gills and gut samples }(\mathrm{p}>0.05) \\
\text { c significant differences between Enterobacteriaceae in roach and bream skin, gill and gut samples were ol }\end{array}$} \\
\hline
\end{tabular}

The higher TBC in comparison with coliforms and Enterobacteriaceae in chub, roach, bream, perch and crucian carp is attributable to the widespread occurrence of microorganisms in the aquatic environment. Coliforms and Enterobacteriaceae are hygiene indicators and their counts generally are lower, because they indicate a contamination and the possible presence of pathogenic bacteria in fish and aquatic environment.

In the present study, the TBC, Enterobacteiacea counts were in line with Austin (2006) reported for Atlantic salmon and rainbow trout with skin contamination rates of $10^{2}$ to $10^{3} \mathrm{CFU} \mathrm{g}{ }^{-1}$ and from 10 to $10^{7} \mathrm{CFU} \mathrm{g}^{-1}$ in skin samples, respectively. However, the present results were less than reported for perch and bream sampled from Usmas lake in Latvia with skin contamination of 5.48 and $7.07 \log _{10}$ CFU $\mathrm{g}^{-1}$, respectively (Terentjeva et al., 2015). As the water microbiological quality, angling method and hygiene are crucial in providing of the microbiological quality of fish, the bacterial counts can vary in great extent that could be an explanation for differences in the reports (González et al., 1999). In our mind, the microbiological quality of caught fish was good and indicated that the fish were caught from a clean environment.

The lowest bacterial contamination with TBC, Enterobacteriaceae and coliforms was observed in skin, while the highest - in the gill and gut. Since the contamination of skin fish from surrounding environment, including fisherman hands, is possible, the results show that the skin contamination could be avoided. Our results are in agreement with Austin (2006), who reported that fish skin contains the relatively less amount of bacteria than other tissues. In contrast, TBC from $10^{12}$ to $10^{13} \mathrm{CFU} \mathrm{g}^{-1}$ were reported on skin of tilapia in Nigeria (Oreochromis niloticus) that emphasize the importance of hygienic handling of fish and storage conditions (Emikpe et al., 2011).

In our study, the high bacterial contamination in gills was observed. The gills usually share a large number of bacteria - up to $10^{6} \mathrm{CFU} \mathrm{g}^{-1}$ (Austin, 2006). The reason for the relatively high amount of bacteria is the precipitation of water and other organic substances, including bacteria during the water filtration (Austin, 2006).

Our study revealed that the highest bacterial contamination was found in the fish gut. Austin (2006) stated that the highest bacterial population was observed in the fish digestive tract and TBC varied from $10^{5}$ to $10^{8} \mathrm{CFU} \mathrm{g^{-1 }}$. Composition and counts of microflora in fish gut depend on many factors, but the most important are water quality, fish species, age and the type of feed. Herbivore fish receives additional bacteria from aquatic plants, but predator fish from other living organisms, so in that fish more microorganisms can be found in the gut than in other tissues (Bacanu, Oprea, 2013).

Pathogenic bacteria - Salmonella spp., Listeria spp. and Yersinia spp. were not identified in the present study, however, the Listeria monocytogenes and Yersinia spp. were isolated from freshly caught fish in Latvia previously (Terentjeva et al., 2015). Our results indicate that the freshly caught fish were safe for consumption.

Bacterial contamination of the fish caught in the pond was higher in comparison with the fish caught in Driksna river (Figure 1). Despite the TBC was 
higher in the skin of fish caught in Driksna river (3.68 $\log _{10} \mathrm{CFU} \mathrm{\textrm {g } ^ { - 1 }}$ ), the TBC in gill and gut were higher in fish caught in the pond, 4.54 and $4.78 \log _{10}$ CFU $\mathrm{g}^{-1}$, respectively. Also, the highest coliform counts were detected in fish from the pond $-2.55,4.10$ and $3.64 \log _{10} \mathrm{CFU} \mathrm{g}^{-1}$ in skin, gills and gut, respectively. The highest Enterobacteriaceae counts were obtained from fish from the pond as well with $1.95,4.05$ and $3.25 \log _{10} \mathrm{CFU} \mathrm{g}{ }^{-1}$ in skin, gills and gut, accordingly.

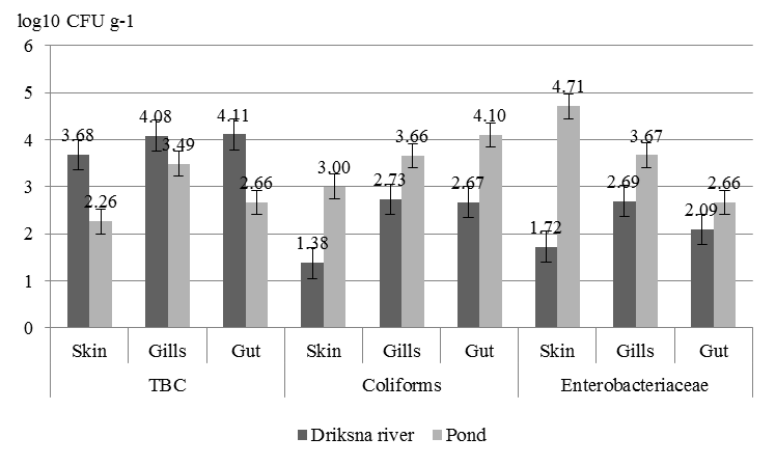

Figure 1. Bacterial contamination of freshwater fish caught in Driksna river and pond

Prevalence and survival conditions for microorganisms in rivers significantly differ from those in lakes and ponds. In rivers, as compared to ponds, the longer coastline, the higher speed of water flow and quantity of the substance exchange protect the water from exceeding contamination with microorganisms. In contrast, in the ponds, water exchange is not possible, thus in such water bodies, the increased concentration of different substances and microorganisms were observed (Bronmark, Lars-Anders, 2005; Kḷaviņš, Cimdin̦š, 2004).

Among all microbial genera were isolated from freshwater fish, the majority belonged to bacteria with Pseudomonas spp. (55\%), Pantoea spp. (9\%), Serratia spp. (7\%) and Rahnella spp. (7\%) were predominant. Candida spp. (6\%) was only the microscopic yeasts isolated (Figure 2).

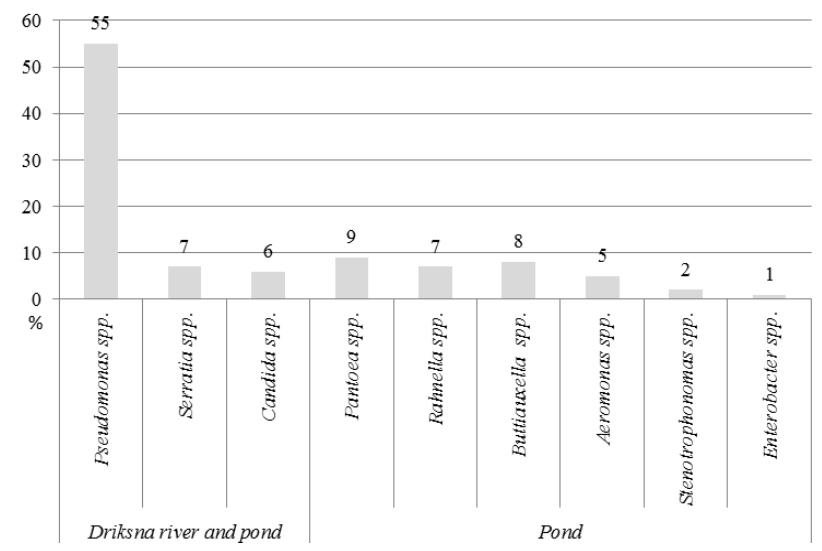

Figure 2. Microflora of freshly caught freshwater fish

Pseudomona spp., Serratia spp. and Candida spp were isolated from freshwater fish caught in Driksna river.
Pseudomona spp., Serratia spp., Candida spp., Pantoea spp, Rahnella spp., Buttiauxella spp., Aeromonas spp., Stenotrophonomas spp. and Enterobacter spp. were identified in freshwater fish caught in the pond. Microflora of freshly caught freshwater fish from the pond was more diverse than in fish from Driksna river. Pseudomonas spp. were isolated from both freshwater fish sampling sites - from the river and the pond.

Pseudomonas are well-known fish specific spoilage microorganisms and their abundance in fish may led to rapid fish spoilage processes that causes changes in fish meat quality and makes fish unfit for human consumption (Gillespie, 1981; Gram, Dalgaard, 2002). Serratia spp., Pseudomonas spp., Rahnella spp. and Pantoea spp. were isolated from rainbow trout (Oncorhynchus mykiss) and bacterial microflora composition corresponds to our study (Austin, 2006). Serratia spp. Rahnella spp. and Pantoea spp. are present in the environment, plant surfaces, soils and water (Blackburn, 2006). Serratia spp. have been isolated from fish and other foods. The bacteria are able to grow in an environment that is unsuitable for other microbial growth and Serratia spp. also contribute to spoilage of foods. Candida spp. can be found in both contaminated and clean waters - rivers, lakes and ponds. Consequently, this microscopic yeast was previously isolated from fish and aquatic components (Batt, 2014). Aeromonas spp. is an opportunistic pathogen found in freshwater habitats around the world, in soil, water and food. This bacteria can cause foodborne and nosocomial infections (Cabral, 2010; Gauthier, 2015; Janda, Sharon, 2010). The presence of this microorganisms potentially may cause consumer health concerns.

\section{Conclusions}

All the freshly caught fish obtained from fishermen exhibit satisfactory microbiological quality with crucian carp (Carassius carassius) was the most contaminated fish among all the tested species.

The Pseudomonas spp. was predominant in fish microflora in all cases. Pseudomonas spp. cause rapid deterioration of fish and fish products and the dominance of this bacterial group indicates that the fish are prone to spoilage process development.

\section{Acknowledgment}

Work was funded by Grant Agency VEGA 1/0411/17.

\section{References}

1. Austin B. (2006) The bacterial microflora of fish. The Scientific World Journal, Vol. 6, p. 931-945.

2. Bacanu G. M., Oprea L. (2013) Differences in the gut microbiota between wild and domestic Acipenser ruthenus evaluated by denaturing gradient gel electrophoresis. Romanian Biotechnology Letter, Vol. 18, p. 8069-8076.

3. Batt C. A., Robinson R. K. (2014) Encyclopedia of Food Microbiology. Second ed. Academic Press. 3248 p. 
4. Blackburn C. W. (2006) Food Spoilage Microorganisms. Woodhead Publishing. $712 \mathrm{p}$.

5. Bronmark C., Lars-Anders H. (2005) Biology of Lakes and Ponds. Second ed. Oxford: Oxford University Press. $596 \mathrm{p}$.

6. Cabral J.P.S. (2010) Water Microbiology. Bacterial Pathogens and Water. Int. J. Environ. Res. Public Health, Vol. 7, p. 3657-3703.

7. Davies A. R., Cpell C., Jehanno D., Nychas G.J.E., Kirby R.M. (2001) Incidence of foodborne pathogens on European fish. Food Control, Vol. 12, p. 67-71.

8. Emikpe B. O., Adebisi T., Adedeji O. B. (2011) Bacteria load on the skin and stomach of Clarias gariepinus and Oreochromis niloticus from Ibadan, South West Nigeria: Public health implications. Journal of Microbiology and Biotechechnology Research, Vol. 1, p. 52-59.

9. FAO (2000) The state of world fisheries and aquaculture. FAO, Rome, Italy. [accessed on 25.01.2017.]. Available: http://www.fao.org/docrep/003/x8002e/x8002e00.htm

10. Feldhusen F. (2000) The role of seafood in bacterial foodborne diseases. Microbe and Infection, Vol. 2, p. $1651-1660$.

11. Gauthier D. T. (2015) Bacterial zoonoses of fishes: A review and appraisal of evidence for linkages between fish and human infections. The Veterinary Journal, Vol. 203, p. 27-35.

12. Gillespie N.C. (1981) A numerical taxonomic study of Pseudomonas-like bacteria isolated from fish in southeastern Queensland and their association with spoilage. Journal of Applied Bacteriology, Vol. 50, p. 29-44.

13. González C.J., López-Díaz T.M., García-López M.L., Prieto M., Otero A. (1999) Bacterial microflora of wild brown trout (Salmo trutta), wild pike (Esox lucius), and aquacultures rainbow trout (Oncorhynchus mykiss). Journal of Food Protection, Vol. 62(11), p. 1270-1277.

14. Gram L., Dalgaard P. (2002) Fish spoilage bacteria problems and solutions. Current Opinion in Biotechnology, Vol. 13(3), p. 262-266.
15. Hosseini H., Cheraghali A.M., Yalfani R., Razavilar V. (2004) Incidence of Vibrio spp. in shrimp caught of south coast of Iran. Food Control, Vol. 15, p. 187-190.

16. Huss H. H. (1997) Control of indigenous pathogenic bacteria in seafood. Food Control, Vol. 8, p. 91-98.

17. ISO 10273 (2003) Microbiology of food and animal feeding stuffs - Horizontal method for the detection of presumptive pathogenic Yersinia enterocolitica.

18. ISO 11290-1 (2005) Food microbiology - Horizontal method for detection and enumeration of Listeria monocytogenes.

19. ISO 21528-2 (2004) Microbiology of food and animal feeding stuffs - Horizontal methods for the detection and enumeration of Enterobacteriaceae - Part 2: Colonycount technique.

20. ISO 4832 (2006) Microbiology of food and animal feeding stuffs - Horizontal method for the enumeration of coliforms - Colony-count technique.

21. ISO 4833 (2003) Microbiology of food and animal feeding stuffs - Horizontal method for the enumeration of microorganisms - Colony-count technique at 30 degrees $\mathrm{C}$.

22. ISO 6579 (2006) Microbiology of food and animal feeding stuffs - Horizontal method for the detection of Salmonella spp.

23. Janda J. M., Sharon L. A. (2010) The genus Aeromonas: taxonomy, pathogenicity, and infection. Clinical microbiology reviews, Vol. 23(1), p. 35-73.

24. Kḷaviņš M., Cimdiņš P. (2004) Ūdeñu kvalitāte un tās aizsardzība. Rīga: LU Akadēmiskais apgāds. 204 lpp.

25. Rohde A., Hammerl J. A, Appel B., Dieckmann R., Al Dahouk S. (2014) FISHing for bacteria in food - A promising tool for the reliable detection of pathogenic bacteria? Food Microbiology, Vol. 46(1), p. 395-407.

26. Terentjeva M., Eizenberga I., Novoslavskij A., Strazdiņa V., Valciņa O., Ošmjana J., Bērziņš A. (2015) Bacterial microflora of freshwater fish originated from Usmas Lake in Latvia. The Journal of Microbiology, Biotechnology and Food Sciences, Vol. 4, p. 74-77. 